\begin{tabular}{|l|l|l|}
\hline \multicolumn{2}{|c|}{ PublisherInfo } \\
\hline \hline PublisherName & $:$ & BioMed Central \\
\hline \hline PublisherLocation & $:$ & London \\
\hline \hline PublisherImprintName & $:$ & BioMed Central \\
\hline \hline
\end{tabular}

\title{
Reaping the rewards of RNAi
}

\begin{tabular}{|l|l|l||}
\hline \multicolumn{2}{|c|}{ ArticleInfo } \\
\hline \hline ArticleID & $:$ & 4679 \\
\hline \hline ArticleDOI & $:$ & $10.1186 /$ gb-spotlight-20030116-01 \\
\hline \hline ArticleCitationID & $:$ & spotlight-20030116-01 \\
\hline \hline ArticleSequenceNumber & $:$ & 31 \\
\hline \hline ArticleCategory & $:$ & Research news \\
\hline ArticleFirstPage & $:$ & 1 \\
\hline \hline ArticleLastPage & $:$ & 2 \\
\hline \hline & & RegistrationDate : 2003-1-16 \\
\hline ArticleHistory & $:$ & OnlineDate \\
\hline \hline ArticleCopyright & $:$ & BioMed Central Ltd2003-16 \\
\hline \hline ArticleGrants & $:$ & \\
\hline \hline ArticleContext & $:$ & 130594411 \\
\hline \hline
\end{tabular}




\section{Jonathan B Weitzman}

Email: jonathanweitzman@hotmail.com

Loss-of-function phenotype analysis in nematode worms has benefited tremendously from a wellannotated genome and the efficacy of RNAi gene-inactivation technology. In the January 16 Nature Kamath et al. report the results of the first genome-wide RNAi screen in Caenorhabditis elegans (Nature 2003, 421:231-237). Worms were fed on bacteria expressing double-stranded RNA for each $C$. elegans target gene. A library of 16,757 bacterial strains, covering $87 \%$ of predicted genes, was screened for genes implicated in sterility, embryonic lethality, slow growth or post-embryonic defects. About $10 \%$ of strains gave clear mutant phenotypes. The most common RNAi phenotype is embryonic lethality. Worm genes that were orthologs in other species are more likely to have a detectable RNAi phenotype than other genes. And genes that exist as a single copy are 2-3 times more likely than others to have a phenotype. Some protein domains showed association with particular types of RNAi phenotypes. Also, genes with RNAi phenotypes are often found grouped together in chromosomal clusters. In an accompanying paper, Ashrafi et al. describe how this RNAi library can be used as a powerful resource to identify genes that regulate body fat production (Nature 2003, 421:268-272). In an accompanying 'News and Views' article Thomas Tuschl comments that these studies establish "a new standard for systematic, genome-wide genetic studies."

\section{References}

1. WormBase, [http://www.wormbase.org]

2. Potent and specific genetic interference by double-stranded RNA in Caenorhabditis elegans.

3. Nature, [http://www.nature.com]

4. Transcriptional territories in the genome.

This PDF file was created after publication. 